\title{
Double-blind therapeutic trial of isoniazid in 344 patients with uveitis
}

\author{
T. F. SCHLAEGEL, JR., AND J. C. WEBER
}

From the Department of Ophthalmology, Indiana University School of Medicine, Indianapolis, Indiana, U.S.A.

Isoniazid appeared to offer exciting possibilities in the treatment of uveitis when the drug became available in 1952, because tuberculosis was then considered to be the chief cause of endogenous uveitis. Gordon (1960), however, stated that tuberculosis was rarely, if ever, a cause of uveitis, and the number of cases attributed to tuberculosis has been steadily declining (Table I); the present estimate, both in our clinic (Schlaegel, 1969) and in that of Witmer (1964) in Zurich is only I per cent. Some have argued that tubercle bacilli must be present to produce a tuberculous uveitis (Woods, I954), but others have felt that in many cases the condition may be due to an allergic reaction (Ashton, 1955). Convincing cases of allergic origin are those that occur 2 or more days after a tuberculin skin test. The results of the present study, which reports a disappointing response of uveitis to isoniazid, pertain only to the presumed infectious type.

Table I Percentage frequency of presumptive uveitis diagnoses

\begin{tabular}{llllll}
\hline $\begin{array}{l}\text { Granulomatous disease regarded as } \\
\text { aetiological factor }\end{array}$ & $\begin{array}{l}\text { Guyton and } \\
\text { Woods } \\
(1941)\end{array}$ & $\begin{array}{l}\text { Woods and } \\
\text { Guyton } \\
(1944)\end{array}$ & $\begin{array}{l}\text { Woods and } \\
\text { others } \\
(1954)\end{array}$ & $\begin{array}{l}\text { Schlaegel } \\
\text { (1965) }\end{array}$ & $\begin{array}{l}\text { Schlaegel } \\
\text { (1967) }\end{array}$ \\
\hline Tuberculosis & 79 & 52 & 23 & 4 & 1 \\
Syphilis & 16 & 17 & 7 & 0 & 1 \\
Sarcoidosis & 1 & 10 & 6 & 5 & 2 \\
Brucellosis & 1 & 10 & 7 & 0 & 0 \\
Toxoplasmosis & 0 & 0 & 26 & 27 & 18 \\
Histoplasmosis & 0 & 0 & 0 & 22 & 22 \\
Miscellaneous (including viral disease) & 3 & 5 & 13 & 13 & 20 \\
Peripheral uveitis & 0 & 0 & 0 & 0 & 14 \\
Undetermined & 0 & 6 & 18 & 39 & 26 \\
\hline
\end{tabular}

\section{Material and methods}

The isoniazid double-blind test was at first used as a routine diagnostic measure in all cases of uveitis, but was later restricted to those thought most likely to be of tuberculous aetiology. Both placebo and isoniazid tablets were made on the same machine by the same company* and the bottles were labelled by the pharmacy so that the doctors, nurses, and patients did not know whether the placebo or the active isoniazid (100 mg.) was being administered.

After the patient had been examined, he was instructed to take one tablet three times a day and to return for a check in 2 weeks. The bottles were randomized so that about half the patients began treatment with isoniazid and about half with the placebo. A treatment period of 2 weeks was chosen since experiments on animals usually showed a response beginning on about the sixth day of 
treatment (Woods, Becker, and Wood, r954; Knapp and von Sallmann, 1954). We (Schlaegel and Hungerford, 1954); Woods (1954) also had the impression that clinical improvement usually began after I or 2 weeks of therapy.

At the second visit, the patient was again examined and it was decided whether he had responded to treatment $(+)$ or not $(-)$. He was then given the companion bottle and again instructed to $\stackrel{\vec{P}}{\stackrel{P}{(}}$ take one tablet three times a day and to return for another check in 2 weeks. At the third visit it was again decided whether the uveitis had improved $(+)$ or not $(-)$.

After this final grading the pharmacy revealed the order in which the placebo and active isoniazid had been administered. Some potential errors inherent in this experimental design are shown in Table II.

Table II Possible false positive and false negative responses to isoniazid

False positive

(I) Sudden spontaneous or idiopathic improvement

(2) Slight possibility that isoniazid may be active against another cause of uveitis
False negative

(I) Tubercle bacilli may be initially resistant to isoniazid

(2) Massive infection delays a favourable response $N$ for more than two weeks (Kratka, 1955)

(3) Uveitis due to allergy to (rather than infectionfrom) tubercle bacilli

\section{Results}

Of the 344 uveitis patients (Table III), $3^{8}$ improved only on the isoniazid, $3^{8}$ improved only on the placebo, and 58 improved on both. The results of the same therapy in a⿳亠二口犬 control group of 33 patients were not statistically different. Most of the uveitis patients气ू๊ (210) showed no improvement at all.

Table III Response of uveitis patients to isoniazid or placebo

\begin{tabular}{|c|c|c|}
\hline Improvement & Uveitis & Control \\
\hline On isoniazid but not on placebo & 38 & 5 \\
\hline On placebo but not on isoniazid & 38 & 3 \\
\hline On both & 58 & 7 \\
\hline On neither & 210 & 18 \\
\hline
\end{tabular}

$\chi^{2}=0.371 ; P<0.70$

\section{Discussion}

These results fit in with the declining emphasis on the role of tuberculosis in the aetiology of uveitis. This study does not concern those types of uveitis presumed to be due to allergy? to the tubercle bacilli or its products, but only the infectious types.

Table IV shows that allergic tuberculous uveitis is unlikely to occur very frequently $\underset{x \mathbb{D}}{\stackrel{0}{0}}$ since the incidence of a positive tuberculin reaction in uveitis patients was, if anything less than in a control group. 


\section{Summary}

33 control subjects and 344 patients with uveitis (selected from those most likely to have tuberculosis) were given either isoniazid or placebo $100 \mathrm{mg}$. three times a day for two consecutive periods of 2 weeks. The tablets were all exactly the same and neither the patient nor the doctor knew which of the two drugs was administered first and which second. The patients were examined after each 2-week course of therapy. Of the 344 uveitis patients, 38 improved on the isoniazid and failed to improve on the placebo, and 38 improved on the placebo and failed to improve on isoniazid; 58 improved on both, and 2 Io did not improve at all. The results in the 33 control subjects were not statistically different. This evidence suggests that infectious tuberculosis is rarely a cause of endogenous uveitis.

\section{References}

Ashron, N. (1955) “Acta XVII Conc. Ophthal., 1954, Candaa, U.S.A. Acta”, vol. 2, p. I 214.

University of Toronto Press, Canada

GORDON, D. M. (1960) Amer. F. Ophthal., 50, 236

GUYTon, J. s., and woods, A. c. (194I) Arch. Ophthal. (Chicago), 26, 983

KNAPP, P., and von Sallmann, L. (1954) Amer. F. Ophthal., 38, No. I, pt 2, p. 199

KRATKA, w. H. (1955) A.M.A. Arch. Ophthal., 54, 330

SCHLAEGEL, T. F., JR. (1965) Unpublished data

- (1967) Unpublished data

- (1969) "Essentials of Uveitis". Little Brown and Company, Boston. In press and Hungerford, L. N. (1954) A.M.A. Arch. Ophthal., 51, $48 \mathrm{I}$

WITMER, R. H. (1964) In "Immunopathology of Uveitis", ed. A. E. Maumenee and A. Silverstein.

Williams and Wilkins, Baltimore

woods, A. c. (1954) A.M.A. Arch. Ophthal., 52, 174

, BECKER, B., and WOOD, R. M. (1954) Ibid., 51, 242

and GUYTon, J. s. (1944) Ibid., 31, 469

-, JACOBS, L., WOOD, R. м., and cook, м. к. (1954) Amer. F. Ophthal., 37, I63 